Abstracta Iranica Abstracta Iranica

Revue bibliographique pour le domaine irano-aryen

Volume 31 | 2011

Comptes rendus des publications de 2008

\title{
Rome and Persia in Late Antiquity. Neighbours and Rivals. Cambridge, Cambridge University Press, 2007, 347 p.
}

Christelle Jullien

\section{OpenEdition}

1 Journals

\section{Édition électronique}

URL : http://journals.openedition.org/abstractairanica/39475

DOI : 10.4000/abstractairanica.39475

ISSN : 1961-960X

Éditeur :

CNRS (UMR 7528 Mondes iraniens et indiens), Éditions de l'IFRI

\section{Édition imprimée}

Date de publication : 15 mai 2011

ISSN : 0240-8910

Référence électronique

Christelle Jullien, «Rome and Persia in Late Antiquity. Neighbours and Rivals. Cambridge, Cambridge University Press, 2007, 347 p. », Abstracta Iranica [En ligne], Volume 31 | 2011, document 79, mis en ligne le 15 février 2012, consulté le 28 septembre 2020. URL : http://journals.openedition.org/ abstractairanica/39475; DOI : https://doi.org/10.4000/abstractairanica.39475

Ce document a été généré automatiquement le 28 septembre 2020.

Tous droits réservés 


\title{
Rome and Persia in Late Antiquity. Neighbours and Rivals. Cambridge, Cambridge University Press, 2007, $347 \mathrm{p}$.
}

\author{
Christelle Jullien
}

1 Il s'agit de la traduction anglaise du livre paru en 2001 sous le titre Rom und das Perserreich. Zwei Weltmächte zwischen Konfrontation und Koexistenz dans la collection Studienbücher. Geschichte und Kultur der Alten Welt, Berlin.

2 Les AA., suivant l'ordre chronologique des événements politico-militaires qui ont marqué les relations romano-perses, ont eu soin d'intégrer un corpus significatif de textes venant illustrer le propos. Plusieurs chapitres sont dévolus aux régions limitrophes et royaumes vassaux: Hatra, Palmyre, Hira, Arménie. Un chapitre est consacré aux relations entre chrétiens et zoroastriens, avec des extraits choisis de sources. L'ouvrage s'achève par deux exposés, l'un sur le concept de "famille royale" et de "légitimité", l'autre sur les échanges culturels entre les deux empires. Cet aspect est surtout traité en fonction des liens d'ambassade, d'espionnage, mais aussi à travers les déportations de prisonniers sur les sols perse et romain. Plusieurs appendices peuvent être utiles (liste des souverains sassanides, chronologie, glossaire).

\section{INDEX}

Thèmes : 3.2.3. Séleucides, Parthes et Sassanides 
AUTEURS

CHRISTELLE JULLIEN

CNRS, Mondes iranien et indien - Paris 